\title{
PERKEMBANGAN TEKNOLOGI DALAM MEMBANGUN INOVASI PENDIDIKAN
}

\author{
M.Ian Erwin Najamudin \\ Email: peramuan27@gmail.com \\ Program Studi Pendidikan Sejarah fakultas keguruan dan pendidikan \\ Universitas Lambung Mangkurat \\ Banjarmasin
}

\begin{abstract}
Abstrak
- Inovasi pendidikan adalah. Interaksi kemajuan instruktif merupakan perkembangan latihan yang diselesaikan oleh orang / asosiasi, dari memantau perkembangan hingga melaksanakan (melaksanakan) perkembangan instruktif. Kata interaksi menunjukkan bahwa tindakan tersebut diselesaikan dengan membutuhkan energi yang serius dan jelas perubahan terjadi tanpa gagal, mempertimbangkan bahwa pengajar dapat menjadi bagian yang vital dalam tindakan pengarahan dan pembelajaran di ruang belajar, hendaknya memiliki pilihan untuk mengembangkan kapasitasnya. membuat media pembelajaran yang layak dan efektif. karena kemajuan waktu yang berlangsung terus menerus dengan jangka waktu tertentu. Dengan kemajuan inovasi data, pendidik tidak hanya sekedar menjadi moderator data, salah satunya adalah pemanfaatan perkembangan dimana media yang digunakan dalam pembelajaran sejarah telah mengalami kemajuan dengan pemanfaatan aplikasi pembelajaran berbasis. telepon seluler serba guna. Dengan kemajuan inovasi data, pendidik berperan sebagai moderator data, tetapi juga harus memiliki pilihan untuk bertindak sebagai fasilitator, asisten, dan pemandu yang memberikan lebih banyak kebebasan kepada siswa untuk menemukan dan menangani data tanpa orang lain. Dengan cara ini, penguasaan pendidik harus terus diciptakan dan tidak hanya dibatasi untuk mendominasi standar pengajaran seperti yang digambarkan dan diberikan
\end{abstract}

\section{PENDAHULUAN}

Interaksi kemajuan instruktif merupakan perkembangan latihan yang diselesaikan oleh orang / asosiasi, dari memantau perkembangan hingga melaksanakan (melaksanakan) perkembangan instruktif. Kata interaksi menunjukkan bahwa tindakan tersebut diselesaikan 
dengan membutuhkan energi yang serius dan jelas perubahan terjadi tanpa gagal. Berapa jumlah waktu yang dibutuhkan siklus untuk tempat akan bergeser dari satu individu ke individu lain atau asosiasi bergantung pada pengaruh individu atau asosiasi terhadap kemajuan; Ukuran pengembangan instruktif memiliki empat fase, yaitu: Penciptaan (disclosure), (perbaikan), Diseminasi (penyebaran) Apropriasi (retensi) Kemajuan instruktif adalah kemajuan untuk mengurus masalah dalam pelatihan. Kemajuan instruktif menggabungkan hal-hal yang diidentifikasi dengan segmen kerangka sekolah, baik dalam arti sempit, untuk lebih spesifik tingkat organisasi instruktif, seperti dalam istilah yang luas, khususnya kerangka pelatihan publik. Pengembangan dalam pelatihan bisa berupa apa saja, item atau kerangka kerja. Misalnya item, pendidik membuat model media pembelajaran untuk pembelajaran. Kerangka kerja misalnya adalah cara menyampaikan materi di kelas dengan tanya jawab atau strategi yang berbeda. Kemajuan dapat dilakukan dengan pemanfaatannya, yang membuat hal-hal baru, mempermudah dalam dunia persekolahan, dan mendorong kemajuan. Perkembangan di sekolah terjadi pada sistem pendidikan yang memasukkan bagian-bagian yang ada. Diantaranya adalah kerangka instruksi sekolah yang terdiri dari program pendidikan, pedoman, dan dewan asosiasi fokus aset pembelajaran. Begitu sangat pesat sebuah perkembangan pengembangan dilakukan dalam kerangka pembelajaran (yang berperan di dalamnya adalah pendidik) karena instruktur dengan lugas memimpin pembelajaran di ruang belajar. Prestasi belajar sebagian besar merupakan tugas pendidik. Kemajuan instruktif adalah pemikiran, hal, strategi yang dilihat atau dilihat sebagai sesuatu mudah kita bagkani kepada individu atau kumpulan individu (masyarakat), baik sebagai pembalikan (wahyu baru) atau pengungkapan (yang akhir-akhir ini ditemukan oleh individu), yang dapa dicapai untuk instruktif atau untuk menangani masalah saat ini. ( Anis, M. Z. A., Putro, H. P. N., Susanto, H., \& Hastuti, K. P. (2020): 7899)

\section{PERAN GURU SEBAGAI SEBUAH PROFESI}

Karena peran pendidik dalam pemajuan dan peningkatan media pembelajaran sangat penting, dengan mempertimbangkan bahwa pengajar dapat menjadi bagian yang vital dalam tindakan pengarahan dan pembelajaran di ruang belajar, hendaknya memiliki pilihan untuk mengembangkan kapasitasnya. membuat sebuah pembelajaran sanagat layak dan efektif. karena kemajuan waktu yang berlangsung terus menerus dalam kemajuan. Organisasi instruktif seharusnya tidak hanya senang dengan strategi dan prosedur lama, yang menekankan teknik 
pengulangan, jadi praktis tidak penting jika saat ini diterapkan. Kemajuan pesat periode ini membuat pelajar semakin mengenal berbagai hal baru, seiring dengan perkembangan jagat data dan korespondensi. Sejalan dengan hal tersebut, kondisi ini lazimnya harus diperhatikan oleh para instruktur untuk terus melakukan pengembangan (advance). Untuk memiliki opsi untuk merancang interaksi pembelajaran dengan cara yang kreatif yang dapat memberikan pertemuan yang bermanfaat bagi siswa, kita perlu fokus pada bagian penting dari siklus pembelajaran. Dari bagian-bagian siklus pembelajaran, pendidik dapat merancang latihan dan teknik pembelajaran yang sesuai dengan tujuan pembelajaran. Prosedur peningkatan pembelajaran ini penting karena terdapat beberapa masalah dalam siklus pembelajaran yang mungkin ada dalam kerangka pembelajaran. Dari sudut pandang seorang pendidik, misalnya, penting untuk sebuah pencapayan dengan nasib siswa. Ini menyiratkan bahwa pendidik perlu memiliki pengalaman yang terletak di masa depan. Akibatnya, instruktur harus secara konsisten memberikan data paling mutakhir di bidang yang mereka didik. Pendidik adalah situasi penting untuk penguatan dan pembelajaran suatu negara yang tidak dapat digantikan oleh komponen apa pun dalam keberadaan suatu negara sejak beberapa waktu yang lalu. Semakin kritis kehadiran instruktur dalam menyelesaikan pekerjaan dan kewajibannya, semakin terjamin kualitas pembentukan dan peningkatan status seseorang.. (Susanto, 2020: 16 ).

Salah satunya adalah pemanfaatan inovasi dimana media yang digunakan dalam pembelajaran sejarah telah maju dengan memanfaatkan Aplikasi Pembelajaran Multiguna Serbaguna. Dengan kemajuan inovasi data, instruktur tidak hanya bertindak sebagai moderator data, Salah satunya adalah pemanfaatan inovasi dimana media yang digunakan dalam pembelajaran sejarah telah maju dengan pemanfaatan aplikasi pembelajaran berbasis telepon seluler serba guna. Dengan kemajuan inovasi data, pendidik berperan sebagai moderator data, tetapi juga harus memiliki pilihan untuk bertindak sebagai fasilitator, asisten, dan pemandu yang memberikan lebih banyak kebebasan kepada siswa untuk menemukan dan menangani data tanpa orang lain. Dengan cara ini, penguasaan pendidik harus terus diciptakan dan tidak hanya dibatasi untuk mendominasi standar pengajaran seperti yang digambarkan dan diberikan. Ponsel dapat digunakan sebagai moda pembelajaran sejarah karena dapat menangani data dan mencari data untuk kedua pengajar dan siswa. Dalam waktu komputerisasi, pemanfaatan inovasi mempengaruhi pembelajaran. Alasan penggunaan aplikasi pembelajaran ini adalah untuk menyajikan sejarah lingkungan tempat pemberontakan aktual di Kalimantan Selatan. Sejarah 
terdekat adalah bagian penting dari pengaturan sejarah publik. Melalui media aplikasi pembelajaran, siswa dengan mudah dapat mempelajari materi sejarah sekitar, salah satunya tentang saat-saat pergolakan yang sebenarnya terjadi di Kalimantan Selatan. Aplikasi pembelajaran dimaksudkan untuk digunakan secara mandiri oleh pelajar kapanpun dan dimanapun melalui ponsel portabel mereka. Sejalan dengan itu, realitas terbatas untuk merenungkan sejarah lingkungan bisa bertahan.( Susanto, H., \& Akmal, H. 2018:204)

\section{GURU INDONESIA DAN TANTANGAN PROFESIONALISME}

Dalam aplikasi sehari-hari pembelajaran bisa dilakukan peralatan yang berbeda terutama PC Selain itu, telepon seluler portabel. PC yang kebetulan memiliki struktur yang lebih sedikit moderasi membuat individu tidak biasa membawanya, itu beragam dengan portable ponsel yang memiliki bentuk berbeda dan sangat moderat tidak jarang individu membawanya kemanapun mereka pergi. Selain daripada itu, ponsel portabel adalah gadget yang luar biasa hard yang memiliki bermacam-macam highlight bisa dibilang sebanding dengan PC. Di bidang persekolahan secara khusus belajar, ponsel serbaguna digunakan untuk membantu instruktu Sama seperti siswa yang mencari data yang berbeda olahraga. Kadang-kadang digunakan perkantoran adalah web. Melalui kantor web, instruktur dan siswa dengan mudah dapatkan data latihan. Kantor web ditemukan di ponsel portabel pasti berharga membantu interaksi pembelajaran. Bagaimanapun kapanpun dianalisa lebih dalam lagi kok ponsel serbaguna punya banyak hal kantor yang berbeda, salah satunya adalah aplikasi menemukan yang dianggap cocok mendukung pembelajaran. telah di aplikasi pembelajaran memiliki manfaat berbeda yang ia bisa membantu instruktur dan siswa di belajar. Tidak ada pengecualian di dalam pembelajaran sejarah. Sejarah itu adalah investigasi tindakan orang-orang di masa lalu yang terbukti tidak mampu terlihat merangkul di sini dan sekarang membuat subjek ini layak sulit untuk diinstruksikan. Guru mengalami kesulitan menyampaikan kejadian asli yang terjadi di masa lalu dalam terang warisannya umumnya sebagai barang atau barang langka kuno yang tidak bisa diremehkan.( Susanto, H., \& Akmal, H. (2018).

Ketika sekarang pandangan dunia penggunaan media telah berpindah dari tradisional ke saat ini. Media saat ini tidak dapat dibedakan dengan inovasi, media ini sering dimanfaatkan oleh para pendidik dan siswa untuk membantu siklus pembelajaran. Selain sederhana, tahap 
pengaturan media juga tidak membingungkan karena perangkat seperti proyektor LCD, speaker yang diperkecil, atau workstation yang berguna digunakan.. Sebuah pembelajaran seharusnya bisa berjalan pada sebuah titik ketika telah sampai pada tujuan di manasiswa bisa mengasah kemampuan pikirkan dan dapatkan angka informasi yang berguna baginya. Semua hal dianggap sama, ada penghalang mencapai tujuan ini. Satusalah satunya adalah kegagalan pendidik. Salah satu media pembelajarannya adalah film naratif. Narasi film termasuk dalam kelas media umum dengan alasan menunjukkan gambar gerakan bergabung dengan isyarat audio, satu metode inovatif dalam memperkenalkan data dengan alasan yang menyinggung kepastian target Memiliki nilai fundamental dan eksistensial dalam pembelajaran, narasi media film memiliki manfaat (1) pada premis konkret menggambarkan suatu peristiwa Media Film Naratif dan Dampaknya pada Kemampuan dalam struktur media umum, sehingga membuat siswa tidak membayangkan; (2) menaklukkan batas-batas keberadaan, buat acara-acara sebelumnya bisa terlihat di masa sekarang; dan (3) memberikan dorongan psikologis kepada siswa untuk berpikir rusak dan kaitkan peristiwa-peristiwa dalam film tersebut dengan hidup sekarang (Susanto, H., Irmawati, I., Akmal, H., \& Abbas, E. W. (2021) : 66)

\section{SIMPULAN}

Inovasi pendidikan adalah inovasi Interaksi kemajuan instruktif merupakan perkembangan latihan yang diselesaikan oleh orang / asosiasi, dari memantau perkembangan hingga melaksanakan (melaksanakan) perkembangan instruktif. Kata interaksi menunjukkan bahwa tindakan tersebut diselesaikan dengan membutuhkan energi yang serius dan jelas perubahan terjadi tanpa gagal mempertimbangkan bahwa pengajar dapat menjadi bagian yang vital dalam tindakan pengarahan dan pembelajaran di ruang belajar, hendaknya memiliki pilihan untuk mengembangkan kapasitasnya. membuat media pembelajaran yang layak dan efektif. karena kemajuan waktu yang berlangsung terus menerus dengan jangka waktu tertentu. Dengan adanya kemajuan teknologi informasi, guru tidak hanya betindak sebagai penyaji informasi, Salah satunya adalah pemanfaatan inovasi dimana media yang digunakan dalam pembelajaran sejarah telah maju dengan pemanfaatan aplikasi pembelajaran berbasis telepon seluler serba guna. Dengan kemajuan inovasi data, pendidik berperan sebagai moderator data, tetapi juga harus memiliki pilihan untuk bertindak sebagai fasilitator, asisten, dan pemandu yang memberikan lebih banyak 
kebebasan kepada siswa untuk menemukan dan menangani data tanpa orang lain. Dengan cara ini, penguasaan pendidik harus terus diciptakan dan tidak hanya dibatasi untuk mendominasi standar pengajaran seperti yang digambarkan dan diberikan Narasi film termasuk dalam kelas media umum dengan alasan menunjukkan gambar gerakan bergabung dengan isyarat audio, satu metode inovatif dalam memperkenalkan data dengan alasan yang menyinggung kepastian target Memiliki nilai fundamental dan eksistensial dalam pembelajaran, narasi media film memiliki manfaat.

\section{REFERENSI}

Anis, M. Z. A., Putro, H. P. N., Susanto, H., \& Hastuti, K. P. (2020). Historical Thinking Model in Achieving Cognitive Dimension of Indonesian History Learning. PalArch's Journal of Archaeology of Egypt/Egyptology, 17(7), 7894-7906.

Anis, M. Z. A., Susanto, H., \& Mardiani, F. (2021, February). Analysis of the Effectiveness of MPBH: The Mains of Mandai as a Saving Food in Banjarmasin Community. In The 2nd International Conference on Social Sciences Education (ICSSE 2020) (pp. 89-94). Atlantis Press.

Efendi, I., Prawitasari, M., \& Susanto, H. (2021). Implementasi Penilaian Pembelajaran Pada Kurikulum 2013 Mata Pelajaran Sejarah. Prabayaksa: Journal of History Education, 1(1), 21-25.

Susanto, H. (2020). Profesi Keguruan. Banjarmasin: FKIP Universitas Lambung Mangkurat.

Susanto, H., \& Akmal, H. (2018). Efektivitas Penggunaan Aplikasi Pembelajaran Berbasis Mobile Smartphone Sebagai Media Pengenalan Sejarah Lokal Masa Revolusi Fisik Di Kalimantan Selatan Pada Siswa Sekolah Menengah Atas. HISTORIA: Jurnal Program Studi Pendidikan Sejarah, 6(2), 197-206.

Susanto, H., Irmawati, I., Akmal, H., \& Abbas, E. W. (2021). Media Film Dokumenter Masuknya Islam Ke Nusantara dan Pengaruhnya Terhadap Keterampilan Berpikir Kritis Siswa. HISTORIA: Jurnal Program Studi Pendidikan Sejarah, 9(1). 